\title{
Efficacy of Rhizobacteria to Promote the Growth and Increase the Yield of Several Rice Cultivars
}

\author{
Dewa Ngurah Suprapta* I Gede Rai Maya Temaja \\ Laboratory of Biopesticide, Faculty of Agriculture Udayana University \\ Jl. PB. Sudirman Denpasar Bali Indonesia
}

\begin{abstract}
Rice is still play important role as staple food for most of Indonesian population; consequently Indonesia is greatly relying on rice production to maintain food security. This plant is commonly cultivated with intensive use of synthetic agrochemicals such as synthetic chemical fertilizers and pesticides. However, the improper use of agrochemicals may result in adverse effects to the environment including biotic and abiotic components. This study was conducted to evaluate the efficacy of rhizobacteria formulation to promote the growth and increase the yield of four rice cultivars that commonly grown in Indonesia i.e. Ciherang, Cigeulis, Inpari 33, and IR64. Experiment was done in a green house with three concentrations of rhizobacteria formulation i.e. $0 \%$, $1 \%$, and $2 \%(\mathrm{v} / \mathrm{v})$. Several parameters were observed in this study such as seedling height, leaf chlorophyll content of seedling, plant height at 50 days after transplanting (DAT), leaf chlorophyll content at 50 DAT, number of tillers per plant at 50 DAT, number of productive tillers per plant, and yield per plant. Results showed that significant interactions were observed between rice cultivar and concentration of rhizobacteria formulation in all parameters observed. Rice cultivar IR64 consistently showed superior growth and yield among four rice cultivars tested. Except for cultivar IR64, rhizobacteria concentration at $2 \%$ showed superior results compared to $1 \%$ and $0 \%$ for all parameters observed. This study proved that rhizobacteria formulation containing Stenotrophomonas maltophilia $\mathrm{Sg} 3$ and Enterobacter cloacae A17Kla effectively promoted the growth and increase the yield of four rice cultivars that commonly cultivated in Indonesia, suggested that this rhizobacteria formulation is promising bio-agent to be used for rice production in Indonesia.
\end{abstract}

Keywords: Rhizobacteria, plant growth promotion, rice yield

DOI: $10.7176 / \mathrm{JBAH} / 11-16-03$

Publication date:August $31^{\text {st }} 2021$

\section{Introduction}

Plant production is relying on the use of synthetic chemical fertilizers to provide enough macro nutrients such as $\mathrm{N}, \mathrm{P}$, and $\mathrm{K}$. These macro nutrients are also very important in rice production in Indonesia. The use of macro nutrients in particular $\mathrm{N}$ is not entirely absorbed by the rice plant due to the poor root system. Consequently, part of $\mathrm{N}$ will remain in the soil; some lost because of evaporation, leaching through water runoff and potentially pollute water bodies in rivers as well as lakes. In addition, excessive use of $\mathrm{N}$ results in the plant growth become weak and susceptible to several plant pathogens such as blast disease caused by Magnaporthe grisea Barr (anamorf Pyricularia grisea Sacc., synonym Pyricularia oryzae Cav.) (Kato, 2001). Based on this reason, it is necessary to find bio-agents in particular from plant rhizospheres that posse's ability to enhance the formation of root hairs and improve the root system. Hence will increase the efficiency of absorption of nutrients.

Rice productivity in Indonesia was about 5.14 ton/ha (BPS, 2012) which is relatively lower than other countries such Australia 8.22 ton/ha, Japan 5.85/ton/ha and China 6.06 ton/ha (USDA, 2004). They gave of rice productivity in Indonesia with other rice growing countries suggested that there is a chance to increase the rice productivity through the use of rhizobacteria from rhizospheres of plants.

Several rhizobacteria have been known to have plant growth promotion potential such as Pseudomonas, Enterobacter, Azospirilum, Azotobacter, Burkholderia, Bacillus and Serratia (Alam et al., 2001; Vidyasekaran et al., 1997; Khalimi et al., 2012). Seed treatment with Pseudomonas fluorescens strain Pf1 obviously increased the rice yield (Vidhyasekaran et al., 1997). Rice plant inoculated with Rhizobium sp. IRBG74 increased the rice yield by 11,6\% (Biswas et al., 2000), while Alam et al. (2001) found that treatment by soaking the root of rice seedling for $24 \mathrm{~h}$ with the suspensions of Azotobacter nigricans, A.armeniacus, Bacillus sphaericus, B. megaterium, Enterobacter and Xhantobacter increased the rice yield by $15,03 \%$. Other study done by Khalimi and Suprapta (2012) showed that the treatment with Pantoea agglomerans isolates PaJ and BS2a isolated from the rhizosphere of groundnut increased the yield of rice cultivar Cicih Medang Selem (a local rice variety of Bali) by $154.17 \%$ when compared to control.

As rhizobacteria may have specificity in their host plant, in this study a formulation of rhizobacteria containing Stenotrophomonas maltophilia $\mathrm{Sg} 3$ and Enterobacter cloacae A17Kla was tested for its potential to promote the growth and increased the yield of 4 (four) rice cultivars that commonly cultivated in Indonesia. The aim of this study is to know variation of responses among 4 (four) rice cultivars against rhizobacteria treatment. 


\section{Materials and Method}

Isolates of Rhizobacteria

Two isolates of rhizobacteria used in this study are Stenotrophomonas maltophilia Sg3 isolated from rhizosphere of groundnut (Arachis hypogea) and Enterobacter cloacae Al7Kla was isolated from rhizosphere of Imperata cylindrica. Both of these isolates are maintained in the Laboratory of Biopesticide Faculty of Agriculture Udayana University.

\section{Rice Cultivars}

Four rice cultivars that commonly cultivated by the farmers in Indonesia were tested in this study namely: Ciherang, Cigeulis, Inpari 33, and IR64. The seeds were obtained from agricultural shop in Denpasar Bali.

\section{Formulation Preparation}

Formulation of rhizobacteria was developed with the following ingredients:

$\mathrm{Na}_{2} \mathrm{HPO}_{4} 12 \mathrm{H}_{2} \mathrm{O}(0.3 \mathrm{~g}), \mathrm{KH}_{2} \mathrm{PO}_{4}(0.1 \mathrm{~g})$, potato broth $(200 \mathrm{ml})$, bacto peptone $(1 \mathrm{~g})$, yeast extract $(1 \mathrm{~g})$, dextrose $(10 \mathrm{~g}), \mathrm{NH}_{2} \mathrm{CONH}_{2}(0.1 \mathrm{~g}), \mathrm{P}_{2} 0_{5}(0.5 \mathrm{~g}), \mathrm{K}_{2} \mathrm{O}(0.5 \mathrm{~g}), \mathrm{MgSO}_{4}(0.1 \mathrm{~g})$, leaf extract of aloe vera (100 $\left.\mathrm{ml}\right)$, Tween-80 (20 ml), suspension of Stenotrophomonas maltophilia $\mathrm{Sg} 3\left(10 \mathrm{ml}, 10^{7} \mathrm{CFU} / \mathrm{ml}\right)$, and Enterobacter cloacae Al7Kla $\left(10 \mathrm{ml}, 10^{7} \mathrm{CFU} / \mathrm{ml}\right)$ and water to make one liter. All ingredients except bacterial suspension were sterilized in an autoclave for 20 minutes at $121^{\circ} \mathrm{C}$ and keep under room temperature for about $6 \mathrm{~h}$ and inoculated with bacterial suspension in a laminar air flow cabinet. This formulation is ready for use.

\section{Treatment with Rizobacteria Formulation}

Seeds of five rice cultivars were soaked in sterile distilled water for $24 \mathrm{~h}$, and drained up and kept for $24 \mathrm{~h}$ in a plastic tray under room temperature in the dark for germination. Germinated seeds were then soaked in a formulation at concentration of $2 \%(\mathrm{v} / \mathrm{v})$ for 30 minutes while for control were soaked in sterile distilled water. The treated seeds were then sawn on plastic trays filled with sterile fertile soil and maintained in a green house. The rice seedlings were transplanted 15 days after sowing.

\section{Transplanting}

A factorial experiment with randomized block design were applied in this study consisting of two factors, i.e. factor rice cultivars consisting of 4 levels (Ciherang, Cigeulis, Inpari 33, and IR64)) and factor concentrations of rhizobacterial formulation consisting of 3 levels $(0 \%, 1 \%$, and $2 \%)$. From these two factors, there are 12 combined treatments were tested in this study. Each treatment was replicated three times, thus there are 36 experiment units were prepared. Each experiment unit consisting of 10 pots of rice plants. Plastic pots with diameter $30 \mathrm{~cm}$ filled with fertile soil were used to grow the rice plant. The rice seedlings were pull out and then the roots were dipped for several seconds in a formulation at concentration $0 \%, 1 \%$, and $2 \%$ after which two seedlings each were transplanted into plastic pots filled with fertile soil. All plants were grown in a green house until ready for harvest.

\section{Parameters Observed}

Plant growth parameters such as plant height, number of tillers, leaf chlorophyll content were measured every two weeks after transplanting, while yield components such as number of productive tillers per hill, length of panicle, number of grain per panicle, and weight of grain per hill were determined after harvest.

\section{Data Analysis}

All data were subjected to the analysis of variance (ANOVA) and continued by Duncan,s multiple range test (DMRT) at 5\% level.

\section{Results and Discussion Growth of Rice Seedlings}

The growth of rice seedlings of 5 rice cultivars at 18 days after sowing significantly $(\mathrm{p}<0.05)$ promoted by treatment with rhizobactertia formulation indicated by the plant height and leaf chlorophyll content as presented in Tables 1 and 2. Treatment at concentration of $1 \%$ and $2 \%$ resulted in higher plant height as well as chlorophyll content for all 5 rice cultivar tested. Interaction between rice cultivars and concentration of rhizobacteria concentration was also significant $(\mathrm{p}<0.05)$ suggested that both rice cultivars and concentration of rhizobacteria affected the growth of rice seedling. The highest plant height was obtained from rice cultivar Cigeulis treated with $2 \%$ rhizobacteria concentration (Table 1), while for the highest leaf chlorophyll content was obtained from rice cultivar IR64 (Table 2). 
Table 1. Plant height (in $\mathrm{cm}$ ) of seedlings on four rice cultivars treated with rhizobacteria formulation at $18 \mathrm{~d}$ after sowing

\begin{tabular}{|l|l|c|c|c|}
\hline \multirow{2}{*}{ No } & \multirow{2}{*}{ Rice cultivar } & \multicolumn{2}{|c|}{ Concentration of rhizobacteria formulation (\%) } \\
\cline { 3 - 4 } & & 0 & 1 & 2 \\
\hline 1 & Ciherang & $19.22 \mathrm{~d}^{*}$ & $22.67 \mathrm{c}$ & $23.57 \mathrm{c}$ \\
\hline 2 & Cigeulis & $22.86 \mathrm{c}$ & $29.24 \mathrm{a}$ & $29.28 \mathrm{a}$ \\
\hline 3 & Inpari 33 & $19.85 \mathrm{~d}$ & $23.38 \mathrm{c}$ & $23.86 \mathrm{c}$ \\
\hline 4 & IR64 & $19.48 \mathrm{~d}$ & $27.27 \mathrm{~b}$ & $28.54 \mathrm{ab}$ \\
\hline
\end{tabular}

*Values followed by the same letters are not significantly different according to Duncan's Multiple range tests at $5 \%$ level.

Table 2. Leaf chlorophyll content (SPAD unit) of seedlings on four rice cultivars treated with rhizobacteria formulation at $18 \mathrm{~d}$ after sowing

\begin{tabular}{|l|l|c|c|c|}
\hline \multirow{2}{*}{ No } & \multirow{2}{*}{ Rice cultivar } & \multicolumn{3}{|c|}{ Concentration of rhizobacteria formulation } \\
\cline { 3 - 5 } & & 0 & 1 & 2 \\
\hline 1 & Ciherang & $13.62 \mathrm{f}$ & $24.67 \mathrm{~d}$ & $24.71 \mathrm{~d}$ \\
\hline 2 & Cigeulis & $13.76 \mathrm{f}$ & $25.79 \mathrm{~cd}$ & $26.34 \mathrm{~cd}$ \\
\hline 3 & Inpari 33 & $14.29 \mathrm{f}$ & $27.45 \mathrm{bc}$ & $28.31 \mathrm{~b}$ \\
\hline 4 & IR64 & $17.99 \mathrm{e}$ & $29.18 \mathrm{ab}$ & $30.72 \mathrm{a}$ \\
\hline
\end{tabular}

*Values followed by the same letters are not significantly different according to Duncan's Multiple range tests at $5 \%$ level.

Plant Height, Chlorophyll Content and Number of Tillers

The growth of 5 rice cultivars significantly $(\mathrm{p}<0.05)$ affected by the treatment with rhizobacteria formulation indicated by the plant height, leaf chlorophyll content, and number of tiller measured at 50 days after transplanting (DAT) as presented in Tables 3, 4, and 5. Interaction between rice cultivars and concentration of rhizobacteria formulation was also significant $(\mathrm{p}<0.05)$ for all three parameters observed suggested that both rice cultivars and concentration of rhizobacteria formulation affected plant height, leaf chlorophyll content, and number of tiller per hill measured at 50 DAT. In term of plant height, rice cultivar IR64 treated with rhizobacteria concentration at $2 \%$ showed the highest value $(90.57 \mathrm{~cm})$, while rice cultivar Ciherang treated with $0 \%$ rhizobacteria concentration showed the lowest value $(70.12 \mathrm{~cm})$ as presented in Table 3 . Similar results were also observed on parameters leaf chlorophyll content and number of tiller per hill 50 DAT as shown in Tables 4 and 5.

Table 3. Plant height (in $\mathrm{cm}$ ) of four rice cultivars treated with rhizobacteria formulation at 50 Days after transplanting

\begin{tabular}{|c|l|c|c|c|}
\hline \multirow{2}{*}{ No } & \multirow{2}{*}{ Rice cultivar } & \multicolumn{3}{|c|}{ Concentration of rhizobacteria formulation (\%) } \\
\cline { 3 - 5 } & & 0 & 1 & 2 \\
\hline 1 & Ciherang & $70.12 \mathrm{~h}$ & $75.96 \mathrm{~g}$ & $78.98 \mathrm{f}$ \\
\hline 2 & Cigeulis & $85.54 \mathrm{~cd}$ & $87.59 \mathrm{bc}$ & $89.34 \mathrm{ab}$ \\
\hline 3 & Inpari 33 & $81.23 \mathrm{ef}$ & $85.41 \mathrm{~cd}$ & $87.27 \mathrm{bc}$ \\
\hline 4 & IR64 & $83.58 \mathrm{de}$ & $89.32 \mathrm{ab}$ & $90.57 \mathrm{a}$ \\
\hline
\end{tabular}

*Values followed by the same letters are not significantly different according to Duncan's Multiple range test at $5 \%$ level.

Table 4. Leaf chlorophyll content (SPAD unit) on four rice cultivars treated with rhizobacteria formulation at 50 days after transplanting

\begin{tabular}{|c|l|c|c|c|}
\hline \multirow{2}{*}{ No } & Rice cultivar & \multicolumn{3}{|c|}{ Concentration of rhizobacteria formulation (\%) } \\
\cline { 3 - 5 } & & 0 & 1 & 2 \\
\hline 1 & Ciherang & $37.78 \mathrm{e}$ & $42.13 \mathrm{~cd}$ & $44.74 \mathrm{a}$ \\
\hline 2 & Cigeulis & $41.23 \mathrm{~d}$ & $43.05 \mathrm{abcd}$ & $43.49 \mathrm{abc}$ \\
\hline 3 & Inpari 33 & $41.58 \mathrm{~cd}$ & $42.47 \mathrm{bcd}$ & $44.17 \mathrm{ab}$ \\
\hline 4 & IR64 & $41.56 \mathrm{~cd}$ & $44.22 \mathrm{a}$ & $44.49 \mathrm{ab}$ \\
\hline
\end{tabular}

*Values followed by the same letters are not significantly different according to Duncan's Multiple range tests at $5 \%$ level. 
Table 5. Number of tillers per plant of four rice cultivars treated with rhizobacteria formulation At 50 days after transplanting

\begin{tabular}{|l|l|c|c|c|}
\hline \multirow{2}{*}{ No } & \multirow{2}{*}{ Rice cultivar } & \multicolumn{3}{|c|}{ Concentration of rhizobacteria formulation (\%) } \\
\cline { 3 - 5 } & & 0 & 1 & 2 \\
\hline 1 & Ciherang & $40.07 \mathrm{e}$ & $44.56 \mathrm{~d}$ & $45.62 \mathrm{~d}$ \\
\hline 2 & Cigeulis & $48.19 \mathrm{c}$ & $60.03 \mathrm{~b}$ & $62.18 \mathrm{ab}$ \\
\hline 3 & Inpari 33 & $45.24 \mathrm{~d}$ & $47.40 \mathrm{c}$ & $50.15 \mathrm{c}$ \\
\hline 4 & IR64 & $60.57 \mathrm{~b}$ & $64.26 \mathrm{a}$ & $64.46 \mathrm{a}$ \\
\hline
\end{tabular}

*Values followed by the same letters are not significantly different according to Duncan's Multiple range tests at $5 \%$ level.

\section{Number of Productive Tillers per Plant}

Analysis of variance showed that number of productive tillers per plant of four rice cultivars treated with rhizobacteria formulation at different concentration significantly different $(p<0.05)$ among treatments. Interaction between rice cultivars and concentration of rhizonacteria formulation showed significant $(p<0.05)$ effect to the number of productive tillers per hill. The highest number of tillers per hill (59.78) shown by rice cultivar IR64 treated with rhizobacteria formulation at concentration $2 \%$, while the lowest one was shown by rice cultivar Ciherang treated with $0 \%$ rhizobacteria formulation (33.43) as presented in Table 6.

Table 6. Number of productive tillers per plant of four rice cultivars treated with rhizobacteria formulation 98 days after transplanting

\begin{tabular}{|l|l|c|c|c|}
\hline \multirow{2}{*}{ No } & \multirow{2}{*}{ Rice cultivar } & \multicolumn{3}{|c|}{ Concentration of rhizobacteria formulation (\%) } \\
\cline { 3 - 5 } & & 0 & 1 & 2 \\
\hline 1 & Ciherang & $33.43 \mathrm{~g}$ & $37.60 \mathrm{f}$ & $38.13 \mathrm{f}$ \\
\hline 2 & Cigeulis & $50.69 \mathrm{c}$ & $52.69 \mathrm{bc}$ & $54.74 \mathrm{~b}$ \\
\hline 3 & Inpari 33 & $42.14 \mathrm{e}$ & $47.20 \mathrm{~d}$ & $50.32 \mathrm{c}$ \\
\hline 4 & IR64 & $46.64 \mathrm{~d}$ & $57.50 \mathrm{a}$ & $59.78 \mathrm{a}$ \\
\hline
\end{tabular}

*Values followed by the same letters are not significantly different according to Duncan's Multiple range test at $5 \%$ level.

\section{Yield per Plant}

Based on the analysis of variance, a significant interaction $(p<0.05)$ was observed between rice cultivars and concentration of rhizobacteria formulation regarding their effect to the yield of rice per plant. The highest yield per plant was obtained from cultivar IR64 treated with rhizobacteria formulation at concentration of $2 \%$. Weight of grains for this treatment was $139.55 \mathrm{~g} /$ plant or equal to $15.5 \mathrm{ton} / \mathrm{ha}$. The lowest yield was observed on cultivar Ciherang with only $55.38 \mathrm{~g} /$ plant or equal to $6.1 \mathrm{ton} / \mathrm{ha}$. Interesting result obtained in this study that treatment with rhizobacteria formulation at concentration $1 \%$ was not significantly different $(\mathrm{p}>0.05)$ with that of concentration $2 \%$ in all parameters observed for rice cultivar IR64, while for other rice cultivars treatment with concentration $1 \%$ was significantly different $(\mathrm{p}<0.05)$ with concentration $2 \%$ for most of parameters observed. This result suggested that for rice cultivar IR64 treatment with rhizobacteria formulation at concentration $1 \%$ is enough to promote the growth and increase the yield per plant, while for other cultivars i.e. Ciherang, Cigeulis, and Inpari 33, concentration $2 \%$ is necessary to obtain a maximum both growth promotion and yield per plant.

Treatment with rhizobacteria formulation increased the yield of four rice cultivars between $13,48 \%$ (obtained from rice cultivar Cigeulis treated with $1 \%$ rhizobacteria formulation) to $43.00 \%$ (obtained from rice cultivar Ciherang treated with $2 \%$ rhizobacteria formulation when compared to those treated with $0 \%$ rhizobacteria formulation. These results proved that rhizobacteria formulation effectively increased the yield of four rice cultivars tested in this study.

Table 7. Effects of rhizobacteria formulation to the weight of grain per hill (gram) measured at harvest (98 days after transplanting) on four rice cultivars

\begin{tabular}{|l|l|c|c|c|}
\hline \multirow{2}{*}{ No } & \multirow{2}{*}{ Rice cultivar } & \multicolumn{3}{|c|}{ Concentration of rhizobacteria formulation (\%) } \\
\cline { 3 - 5 } & & 0 & 1 & 2 \\
\hline 1 & Ciherang & $55.38 \mathrm{~h}$ & $72.67 \mathrm{~g}$ & $79.27 \mathrm{f}$ \\
\hline 2 & Cigeulis & $101.58 \mathrm{e}$ & $115.27 \mathrm{c}$ & $121.85 \mathrm{~b}$ \\
\hline 3 & Inpari 33 & $80.15 \mathrm{f}$ & $105,07 \mathrm{~d}$ & $112.62 \mathrm{c}$ \\
\hline 4 & IR64 & $103.81 \mathrm{de}$ & $137.46 \mathrm{a}$ & $139.55 \mathrm{a}$ \\
\hline
\end{tabular}

*Values followed by the same letters are not significantly different according to Duncan's Multiple range tests at $5 \%$ level.

Present study proved that formulation containing rhizobacteria significantly $(\mathrm{p}<0.05)$ promoted the growth of four rice cultivars and increased the yield. The plant height, leaf chlorophyll content, number of tillers per 
plant, number of productive tiller per plant and yield per plant consistently higher on four rice cultivars treated with rhizobacteria formulation $(1 \%$ or $2 \%$ ) when compared to treatment with $0 \%$ formulation. Several studies indicated similar results with our study. Study done by Murphy et al. (2000) showed that treatment of tomato plant with rhizobacteria obviously promoted the plant growth. The growth of plant was increased because rhizobacteria produced growth hormones such as auxin, ethylene, cytokinin and gibberellins which are necessary for plant growth (Husen, 2009).

Several species of rhizobacteria have been reported for their growth promotion to rice plant, such as Pantoea agglomerans (Khalimi et al., 2012); Bradyrhizobium sp. IRBG271 (Biswas et al., 2000); Burkholderia caryophylli ACC7 (Shaharoona et al., 2007), Rhizobium leguminosarum 128C56C (Han and Lee, 2005); Azospirillum brasilense (Kannan and Ponmurugan, 2010). Souza (2012) proved that inoculation of strains Agrobacterium, Burkholderia, Enterobacter, and Pseudomonas could promote the growth of rice. Application of Serratia marcescens NBRI1213 significantly increased the plant height, the dry wight of shoot, root length and dry weight of root of Piper betle L. by $81 \%, 68 \%, 152 \%$ and 290\% respectively (Lavania, 2006). Treatment with Pantoea agglomerans could increase the number of maximum tiller of rice cultivar Cicih Medang Selem by $93.27 \%$ to $120.19 \%$ when compared to control (Khalimi et al., 2012). Othe study done by Hussain et al. (2009) showed that treatment of the root of rice with Mesorhizobium ciceri strain CRI-32 increased the number of maximum tillers by $25,34 \%$.

Other study showed that the number of panicles per plant increased by $92.13 \%$ to $110.95 \%$ by the treatment of Pantoea agglomerans (Khalimi et al., 2012). A study done by Hussain et al. (2009) showed that the rice plants treated with Rhizobium leguminosarum strain LSI-30 could increased the number of panicles per plant by $27.33 \%$. Similar result was also reported by Khorshidi et al. (2011) in which the treatment of rice seedling with suspension of Azosphirillum lipoferum for $12 \mathrm{~h}$ increased the number of grains per panicle by $5.28 \%$.

Treatment with $P$. agglomerans on rice local variety, Cicih Medang Selem, significantly increased the yield per hill, in which the weight of grains per plant on rice treated with isolates $\mathrm{Pj}, \mathrm{Bs}$ and $\mathrm{PB}$ were $114.03 \%$, $134.33 \%$ and $154.17 \%$ higher than that of control (Khalimi et al., 2012). Khorshidi et al. (2011) reported that treatment of rice seedling with the suspension of Pseudomonas fluorescens for $12 \mathrm{~h}$ increased the yield by 33.3\%. Treatment with Pseudomonas fluorescens BRM-32111 and Burkholderia pyrrocinia BRM-32113 was proven to promote the growth of rice. The rice plant inoculated with P. fluorescens BRM-32111 or B. pyrrocinia BRM-32113 resulted in the increase of biomass by $88 \%$, the length of leaf increased by $40 \%$, and chlorophyll content increased by 21\% (Rego et al., 2018). Most $(89.7 \%$ ) of isolates of rhizobacteria isolated from rhizospheres of rice plant in Afganistan produced IAA. Isolates AF134 and AF137 including Enterobacter ludwigii and Pseudomonas putida produced IAA by $92.3 \mu \mathrm{g} \mathrm{mL}-1$. More than $70 \%$ isolates significantly increased dry weight of root and shoot (Habibi et al., 2019). Treatment with Azospirillum lipoferum and Azotobacter chroococcum as seed treatment increased the yield of rice. Number of panicles per $\mathrm{m}^{2}$ and number of grains per panicle increased by $9 \%$ and $18 \%$ respectively (Aminpanah and Firouzi, 2019).

Results of our study enriched the data about the potential and use of rhizobacteria as bio-agent to promote the growth and increase the yield of rice. Hence, the rhizobacteria formulation developed in this study may be used for field testing and further used as an alternative bio-stimulant for rice production.

\section{Conclusion}

Rhizobacteria formulation containing suspension of Stenotrophomonas maltophilia $\mathrm{Sg} 3$, and Enterobacter cloacae A17Kla effectively promoted and increased the yield of four rice cultivars that commonly grown in Indonesia. Responses of four rice cultivars to the treatment with rhizobacteria formulation in term of plant growth parameters and yield to some extent varied among cultivars. Treatment with rhizobacteria formulation increased the yield of four rice cultivars between $13.48 \%$ to $43.00 \%$ when compared to untreated one, suggested that this rhizobacteria formulation potentially may be used to increased rice production in particular in Bali Island, Indonesia. The field test is needed to evaluate the stability and effectiveness of the formulation under real field condition in different localities and season.

\section{Acknowledgement}

We would like to thank The Institute for Research and Community Services, Udayana University for financial support under "Penelitian Produk Inovatif" in fiscal year 2021.

\section{References}

Alam, M.S., Z, J Cui. T.Yamagishi and R. Ishii, 2001. Grain yield and related physiological characteristics of rice plants (Oryza sativa L.) inoculated with free living rhizobacteria. Plant Prod.Sci., 4:126-130.

Aminpanah, H. and S. Firouzi. 2019. Fertilizer Management Using Plant Growth-Promoting Rhizobacteria in Rice Fields. International Journal of Agricultural Management and Development 9(1): 67-76.

Biswas,J.C., J.K.Ladha and F.B. Dazzo, 2000. Rhizobia inoculation improves nutrient uptake and growth of 
lowland rice. Soil Sci.Soc.Am.J.,64:1644-1650.

BPS.2012. Food Crops. Statistics Indonesia.

Han, H.S., and K.D. Lee, 2005. Plant growth promoting rhizobacteria effect on antioxidant status, photosynthesis, mineral uptake and growth of lettuce under soil salinity. Res. J. Agric. Biol. Sci., 1: 210215.

Habibi, S., S. Djedidi, N. Ohkama-Ohtsu, W. A. Sarhadi, K. Kojima, R.V. Rallos, M. D. A. Ramirez, H. Yamaya, H. Sekimoto, and T. Yokoyama. 2019. Isolation and Screening of Indigenous Plant Growthpromoting Rhizobacteria from Different Rice Cultivars in Afghanistan Soils. Microbes Environ. 34(4): 347355.

Husen, E., 2009. Effect of IAA-producing bacteria on the growth of hot pepper. Journal Mikrobiology Indonesia, $8: 22-26$.

Hussain, M.B., I. Mehboob., Z.A. Zahir., M. Naveed and H.N. Asghar, 2009. Potential of Rhizobium spp. for improving growth and yield of rice (Oryza sativa L.). Soil and Environ., 28: 49-55.

Khalimi,K., D.N. Suprapta and Y. Nitta, 2012. Effect of Pantoea agglomerans on Growth Promotion and Yield of Rice. Agricultural Sciense Research Journals, 2: 240-249.

Khorshidi, Y.R., M.R. Ardakani., M.R. Ramezanpour, K. Khavazi and K. Zargari, 2011. Response of yield and yield components of rice (Oryza sativa L.) to Pseudomonas flourescens and Azospirillum lipoferum under different nitrogen levels. American-Erurasian J.Agric.and Environ.Sci., 10: 387-395.

Lavania, P.S., Chauhan, S.V. Chauhan, H.B. Singh and C.S. Nautiyal, 2006. Induction of plant defense enzymes and phenolics by treatment with plant growth-promoting rhizobacteria Serratia marcescens NBRI1213. Curr. Microbiol., 52: 363-368

Murphy, J.F., G.W. Zehnder, D.J. Schuster, E.J. Sikora, J.E. Polston and J.W. Kloepper, 2000. Plant growth promoting rhizobacterial mediated protection in tomato against Tomato mottle virus. Plant Disease, 84: 779784.

Rego, M. C F., A.F. Cardoso, T.C.Ferreira, M.C.C. Filippi, T.F.V. Batista, R.G.Viana, G.B. Silva. 2017. The role of rhizobacteria in rice plants: Growth and mitigation of toxicity. Journal of Integrative Agriculture 17(12): 2636-2647.

Shaharoona, B., G.M. Jamro, Z.A. Zahir, M. Arshad and K.S. Memon, 2007. Effectiveness of various Pseudomonas spp. and Burkholderia caryophylli containing ACC-Deaminase for improving growth and yield of wheat (Triticum aestivum L.). J. Microbiol. and Biotech., 17: 1300-1307.

Souza, R., B. Anelise, A. Adriana, B. Pedro, M. Jacqueline, M. Luciano, K. Vargas, R. Schoenfeld and M.P.P. Luciane, 2012. The effect of plant growth-promoting rhizobacteria on the growth of rice (Oryza sativa L.) cropped in southern Brazilian fields. Journal Plant and Soil. Pp. 1-19.

Suswono. 2012. Rice production of Indonesia decreased 1.08 ton in 2011. Cited on 5th March 2012 from http: //www. zamrudtv.com/ filezam/ nasional/medianasional.php? module $=$ detailnasional $\& \mathrm{id}=3370$

USDA, 2004. Rice yield. Agriculture Statistics. Production Estimates and Crop Assessment Division, FAS, USDA.

Vidhyasekaran and P.M. Muthamilan, 1999. Evaluation of a powder formulation of Pseudomonas fluorescens Pf1 for control of rice sheath blight roots. Biocontrol Science and Technology, 9:67-74 